Немања 3. Каровић

Универзитет у Београду

Учитељски факултет

https://doi.org/10.18485/ai_beckovic.2019.ch8 821.163.41.09-1 Бећковић М.

\title{
МЕТАПОЕТСКА СВЕСТ У РАНОЈ ПОЕЗИЈИ МАТИЈЕ БЕЋКОВИЋА
}

У раду се испитују оглашавања метапоетске свести у збиркама Метак луталица и Тако је говорио Матија Матије Бећковића са интерпретативним настојањем да се прецизније исцрта комплексна поетичка мапа песниковог раног лирског стваралаштва и самери његов однос према естетичким идејама Бранка Миљковића. Посебна пажња посвећена је анализи поетичких осциловања између реафирмисаних романтичарских топоса и обновљених песничких идеја симболистичке провенијенције. Радом је истакнуто сукцесивно смењивање и повремено прожимање међусобно често диспаратних поетских искустава у поезији младог Бећковића и указано на доминантан еклектички однос према песничкој традицији.

Кључне речи: Матија Бећковић, Бранко Миљковић, метапоетска свест, аутопоетика, романтичарска топика, симболизам, модернизам.

Поетички хоризонт првих издања почетних збирки песама неретко бива затомљен наивношћу стваралачког дебитантства, која происходи из младалачки нестрпљиве тежње да се што пре освоји аутентична лирска позиција, некритичке подложности утицајима актуелне поетске моде и недовољне уметничке усаглашености призваних

*nnemanja.karovic@uf.bg.ac.rs 
састојака књижевне традиције. Међутим, подробније херменеутичко истраживање лирских првенаца чини књижевног проучаваоца истовремено сведоком првобитног и отуда јединственог песниковог напора да у пометњи унутрашњих гласова препозна титраје властите поетске речи и тако изнађе полазишну тачку самосвојне поетичке еволуције. У првим поетским објавама, чак и оних песника који се одричу ране поезије или у новим издањима преудешавају изворне стихове, неопозиво је отиснут мање или више видљив и у подједнакој мери варљив зачетни траг њихове укупне песничке судбине.

Прве збирке Матије Бећковића, Метак луталица (1963) и Тако је говорио Матија (1965), почивају на широко заснованој и отвореној позномодернистичкој осећајности, која је довољно слободна да у окриљу поетичке једначине укрсти бројне и разнородне линије песничке традиције, али и одвећ самосвесна да би иједној придала значај апсолутног поетског начела. Отуда Михајло Пантић у Метку луталищи распознаје „многоликог Бећковића, побуњеног лиричара и лирског реторичара, који искушава свој глас на стотину различитих начина” (1995: 188). У метапоетском слоју значења стихова VII сонета „Дежурног ува света”: „Младости моја цвете у рукопису / још праве птице запевале нису” (Бећковић 2013: 13), метафора младости означава еволутивни стадијум једне поетике, а правом мада незапевалом птицом оцртана је жива, али још неостварена жудња за коначним досезањем лирског стајалишта саобразног природи субјекта. Евидентна сложеност поетичке рецептуре почетних песничких објава каткад је, како видимо, условљена управо драматиком темељних поетских самопотрага.

У првим двема Бећковићевим књигама очитује се присуство разноликих и неретко међусобно поетички диспаратних наноса песничког наслеђа: романтичарски став поистовећења песничког искуства и егзи- 
стенције, те готово опсесивна мисао да су бол и ране кључни предуслови уметничког набоја; истицање срца као средишта бића, извора поетске снаге и оне димензије унутрашњег света која не подлеже контроли свести; низ класичних петраркистичких мотива уписаних у љубавно осећање засенчено модернистичком сумњом у семантички досег властитих речи; лирска упризорења ентузијастичког поетичког концепта, односно песничког осећања да је у стиховима садржан диктат незнаних сила; трептаји симболистичке запитаности пред онтолошком тајном песме; неосимболистичком поетиком надахнуто неговање сонетне форме; миљковићевско трагање за истинама чији се сјај пројављује у тренуцима поетски измирених противречности; солипсистички доживљај света; авангардни говорни патос; дрска самоувереност и ритмичка разобрученост руских футуриста; поетско-бунтовнички дух супротстављен репресивном политичком поретку и лирски артикулисан дисидентски отпор тежњи тоталитарне моћи за свеобухватним распростирањем и овладавањем како пољем колективне историје тако и просторном интимом индивидуалне имагинације. Отуда се разумљивом чини читалачка недоумица искрсла над питањем да ли из ране Бећковићеве поезије проговора јединствени песнички субјект, чије је оглашавање из различних поетских регистара заправо спољашњи знак постојања великог унутрашњег поетичког распона, или, пак, очитована поетичка разнородност происходи из лирског вишегласја сабраног страницама књижевних првенаца.

Међутим, једна од сила противтеже, која уцелињујућим дејством очевидну разуђеност Бећковићеве поетске осећајности чини кохерентном и одржава унутар порозних граница јединствене, али каткад до противречности сложене песничке субјективности, јесте сила метапоетске свести, чији су интензитет и фреквентност 
испољавања учинили збирке Метак луталица и Тако је говорио Матија књигама дубоке поетичке самозагледаности. Због тога би интерпретативни закључак Александра Јеркова изречен поводом Бећковићевих најранијих стихова, начелно и са приближно једнаким важењем пристајао и поменутим збиркама: „Недовршени Сонети с краја педесетих година јасно показују потребу субјекта да објави своје постојање и симболички преобликује стање затечено у свету. Одређење песничког субјекта се њему самоме поставља као свемирска загонетка, као да васколики свет у чуду пита ко је он и шта је с њим" (1995: 89-90).

Поступак тирске аутофикиије, крајем педесетих и почетком шездесетих година заступљен и у поезији Милована Данојлића и Бранислава Петровића, а изведен увођењем стварног песниковог имена у домен нестварног поетског света, код Бећковића је присутан на различитим нивоима текста, а обзнањен већ насловима песничких целина: Тако је говорио Матија, „Муке по Матији”, „Матија Бећковић”. ${ }^{1}$ Никола Кољевић је тим поводом приметио: „Нико од наших савремених песника није у тој мери свој идентитет (алфу и омегу своје личности, а не поједини доживљај) преобратио у предмет своје поезије и себе прометнуо у њеног књижевног јунака" (1978: 235). У нареченом контексту лирске самозагледаности овај поступак би се могао, поред осталих значења које поседује, протумачити и као први корак у процесу

1 Аутофикција је термин Сержа Дубровског првобитно употребљен 1977. године на унутрашњој корици књиге Fils. У потоњим теоријским разматрањима примењиван је махом у области аутобиографског, мемоарског и романескног стваралаштва, а често разумеван на прилично контрадикторан начин (в. Душанић 2012). Овај флуидни теоријски појам користимо ван изворног окружења, и то у суженом и конкретним песничким текстовима прилагођеном значењу поетски интенционалног релативизовања границе између фикционалног и фактографског. 
поступног израњања аутопоетичке свести на површину поетског израза.

Непосредно певање о песничкој егзистенцији у првим Бећковићевим збиркама представља један од тежишних тематских кругова, у којем је сабран значајан број стихова метапоетског значења. Стиховима астрофичног сонета којим се отвара Метак луталица: „Срећан је само песник кога снађе / Рана, да нико не упозна тежу” (2013: 7), еминентно романтичарска идеја о нужној дијалектичкој вези певања и страдања није само модернистички реафирмисана већ је истовремено обзнањена као битан чинилац парадоксалне логике песничке егзистенције, према којој страдалништво, метонимијски означено раном, није тек неопходан услов зачећа песника него и разлог потоњег досезања среће унутар поетског постојања. На идентичном противречју семантички почивају и стихови: „Свуд ми је добро ал' у злу најбоље / Конфузна птицо на моју душу пала” (2013: 43) и „тешко ономе кога мимоиђу / Несреће које су му биле намењене" (2013: 7).

Упоредо са почетним устоличењем страдалничке идеје на престоно поетичко место, призвано је и рефлексно превредновање водећих знамења унутрашњег света лирског Ја и последично истицање срца као средишта песничког бића, језгра осећајности и носиоца сабраног бола, али и аутономне области духовног живота чијим је снажним ритмовима самовољности подвлашћена и сама поетска субјективност: „Љубави тражим те по дану са свећом / Срце не прекида везу са несрећом” (2013: 21); „Ова неограничена глава / Клонула у свом срцу клекнула у својој души” (1965: 23); „Моје срце ме држи у затвору и води пред њену кућу” (2013: 62).

Уколико у подручју поетичких постулата Бећковићеве ране поезије страдање задобија смисао предуслова певања, а срце метафорички присваја својства жиже уну- 
трашњег живота, у коју с једне стране утиче бол, а са друге истичу поетске сублимације, онда је посве очекивана, премда уметнички не толико инвентивна, појава стихова значењски заснованих на фигуративном поистовећењу крви и мастила. Издвојени трочлани след аутопоетичких замисли у средишњој целини сонетног триптиха „Муке по Матији” пројављује се у очигледности једноставног мотивског низа: „Правим од срца мастило и пишем / И нећу одустати док се угљенишем. / Неправда само лажном дару смета / Док право семе под теретом цвета. / Са срцем у грлу једак и огорчен / У нужној одбрани са собом суочен” (2013: 22).

Иако би се испољени садржаји Бећковићеве ране метапоетске свести могли контекстуализовати у различитим областима песничке традиције, књижевноисторијски целисходнијим се чини превасходно самеравање са поезијом непосредно претходеће друге генерације српских послератних модерниста, будући да се издвојени аутопоетички ставови у односу према поетици неосимболиста, а нарочито у поређењу са Миљковићевом поетско-естетичком синтезом симболистичког и надреалистичког наслеђа, указују као сасвим опречни. Додатни разлог је чињеница да се у књижевној историји и критици Бећковићев песнички нараштај, којем припадају још и Љубомир Симовић, Бранислав Петровић, Мирјана Стефановић, али и Милован Данојлић и Драган Колунџија, готово доследно оцењује као опозитан, односно превратнички настројен према поетичкој парадигми песника окупљених око Бранка Миљковића (в. Лукић 1973: 152; Палавестра 2012: 226; Негришорац 1999 : 43; Пантић 1999: 100). Истовремено, појединачна појава творца Метка луталице се често сагледава у озрачју препознатих неосимболистичких утицаја (в. Милосављевић 1995: 163-164; Делић 2012: 11; Поповић 2012: 262; Јовановић 2012: 286; Париповић 2012: 380), а у почетној ствара- 
лачкој фази чак и сврстава у шири круг неосимболиста (Ракитић 1984: 11).

У кључној поетеми Миљковићеве гласовите „Баладе”: „Кад мастило сазре у крв, сви ће знати / Да исто је певати и умирати”, али и у њеним завршним стиховима: „Нек срце не оклева. / Исто је певати и умирати” (1997: 132133), није тешко уочити како мотиви певања/умирања, срца и мастила/крви сложеним међусобним односима сачињавају поредак испуњен метапоетским значењима, те да се из законитости на којима је мотивско устројство засновано могу интерпретативно ишчитати нека од маркантних обележја Миљковићеве поетике. Песник, наиме, певајући ступа у поље егзистенцијалног ризика и излаже се опасности губитка властитости, будући да, како Миљковић образлаже у тексту „Орфејско завештање Алена Боскеа”, песма постиже пуну зрелост у часу када се „окренула против песника” (1972: 199). Песма изнутра разара и егзистенцијално празни онога који је ствара, јер га суочава са „настајућом Празнином или Понорима које носи у себи” (Јовановић 1994: 95). Сажето и оштро изражен врхунац настојања лирске творевине да уништи свог творца Радивоје Микић препознаје у језгровитој јасности „познатог епитафа 'уби ме прејака реч” (2003: 287). Стога и Миљковић тврди: „Поезија се пише властитом крвљу”, али имајући притом на уму крв насталу од мастила преобраћеног песничким чином и „болом писања” (1972: 199). У аутопоетичким слојевима значења раних стихова Матије Бећковића обзнањене су истоврсне идеје, али у инверзном поретку, јер код млађег песника страдање не започиње певањем, већ му претходи, те се и крв упоредо са настајањем и сазревањем песничке егзистенције преиначава у мастило.

Да поједини поетички аспекти Бећковићевог почетног стваралачког раздобља успостављају опречан однос према Миљковићевим поетским постулатима, с упадљи- 
вом очигледношћу потврђују очитоване супротности међу овим песницима при лирском третману линија конотативних значења испредених из мотива срца. Естетички вођен Валеријевим идеалом чисте поезије, Миљковић је тежио да пропевалом патетиком ума и неговањем имперсоналних рефлексија песнички свет ослободи чулности и конкретности, то јест очисти од присуства непоетских елемената. Следећи Хераклитову идеју о разарајућем дејству срчаности на грађевине духа и Бодлеров презир према „томе толико осетљивом ткиву међу ребрима, које цеди бол и сузе” (Џаџић 1965: 61), песник „Ариљског анђела” је потискивао срце као знамење рањиве људскости из властитих унутрашњих лирских обзорја и одбацивао одвећ „романтичарско прожимање песме осећањима” (Новаковић 2003: 52): „Јер ако крајности исто сунце доји / Сувишно је срце где песма постоји” (Миљковић 1997: 86). Дакле, управо разлози са којих је симболика овог мотива постала непожељна унутар Миљковићевог песничког универзума, учинили су да се срце у дотицају са лирском осећајношћу Матије Бећковића не само поетски ревитализује већ и да задобије статус повлашћене поетичке фигуре.

Да би се стекла прецизнија и целовитија слика о каткад до противречности сложеној природи раног песништва Матије Бећковића, неопходно је имати у виду и приличан број песама у којима преовлађујући поетички концепт, попут клатна, постепено напушта домен модернистичким сензибилитетом зановљених романтичарских топоса и приспева у поље поетских претпоставки и мотивских комплекса симболистичке провенијенције. Оцртана линија поетичких осциловања зачета је већ стиховима Метка луталице, али се значајније развија у песмама наредне збирке. Наведена путања није сачињена из тачака Бећковићевог унутрашњег развоја, те не представља правац песниковог уметничког само- 
превазилажења и поетичког еволуирања. Дакле, није реч о коначној и неопозивој транзицији из једне стваралачке фазе у другу, већ о сукцесивном смењивању и повременом прожимању међусобно често диспаратних поетских искустава, при чему појединачни поетички чиниоци од песме до песме, из циклуса у циклус, бивају час осетнији и снажније наглашени, а час потиснутији и дискретније присутни. Тиме се очитим указује континуитет Бећковићевог еклектичког односа према разноврсној традицији песничких идеја, због чега би Џаџићево запажање о логици Миљковићевог комплексног поетско-естетичког становишта био, условно говорећи, сасвим прикладан и у случају млађег песника: „Бранко жудно прелистава велику књигу песничких искустава, пребира по слојевитом репертоару поетика, захвата широко, не би ли у пресеку тих бројних, мудрих линија пронашао право место за заставу свог става” (1965: 25).

Отпочевши четврти сонет циклуса „Дежурно уво света” речима: „Знаће се једном све што не говори / о чему ћути" (2013: 10), песнички субјект је, загледан у далеку и неодређену тачку будућег времена, изразио веру у долазак тренутка прожетог есхатолошком пуноћом, који ће објавом смисла закривеног ћутањем ствари утолити епистемолошку жудњу света. Поетска фасцинираност антиципираним часом апсолутне спознаје уочава се и у трећем дистиху друге целине „Птице преко радија”: „Престаће истине да буду метафоре / Кад под притиском мртви проговоре” (2013: 33). Иако изрази метафизичке наде представљају битан моменат Бећковићевог лирског осећања света, поетички претежније значење задобија чињеница да је у садашњици песнички субјект имплицитно истакнут као биће које истанчаном осетљивошћу у „свему што не говори” наслућује присуство недокучивих садржина дубљих од језика и ширих од мисли. Управо суптилно поетско упризорење речитог ћутана ствари, 
сведочанство је субјектовог предосећања, Миљковићевим речником казано, „онтолошког корена песме”, у чему би се могао препознати ненаметљиви позни рефлекс симболистичког идеала поезије без речи (в. Миљковић 1972: 114, 116). Модернистичка тема (не)изрецивости интуитивних спознаја тако постаје једно од незаобилазних поетичких питања ране Бећковићеве поезије.

Непосредније испољавање суверене метапоетске свести проналазимо у завршници деветог сонета „Дежурног ува света", и то унутар стихова који упечатљивост дугују семантичким титрајима једне модернистичке апорије: „Вода је ништа, али песма шта је / Оно што је или што јој недостаје?" (2013: 15). Субјектом је, како видимо, овладао дух фундаменталне поетичке несигурности у часу установљавања где почива или у чему пребива биће песме: у језику стихова или у језички неосвојивој области смисла. У наведеним исказима као да је отиснут траг оне запитаности која се троструким одјеком² зачула у Миљковићевим „Трагичним сонетима”: „Шта је то што се у дну песме крије?" (1997: 41). Првом половином Бећковићевог хипотетичког одговора изречена је могућност да је песма оно umo јесте, у чему се распознаје имплицитна поетичка визура оних песника који су, суочивши се са питањем како речима исцрпсти преобилни свет мисли и осећања, прогласили језик, ,једином поетском стварношћу” и устврдили „да поезија почиње речима и њима завршава, да о поезији изван речи не може бити ни говора" (Миљковић 1972: 225). Другом половином одговора наговештена је поетичка хипотеза да је биће песме настањено у ономе што песми недостаје, што је, дакле, у њој одсутно.

2 Будући да се цитирани стих јавља на крају трећег сонета „Одбацивање сумње”, да би се потом, према логици уланчавања целина сонетног венца, поновио као први стих „Почетка путовања", и коначно, последњи пут обзнанио у првом катрену завршног сонета „Магистрале”. 
Наведена мисао значењски је подударна језгреном месту Миљковићеве поетике, именованом негативном онтологијом, а утемељеном на идеји да је „поезија осет о томе да су ствари ишчезле. Или, тачније, поезија ствара осет одсутне реалности” (Миљковић 1972: 231).

Истоврсном дилемом поетске самосвести обележена је и рана поетика Љубомира Симовића, који са Матијом Бећковићем и Браниславом Петровићем сачињава круг најрепрезентативнијих песника треће етапе српског послератног модернизма. У првом издању Веселих гробова (1961), збирци објављеној две године пре Бећковићевог Метка луталице, песнички субјект мирним тоном самоувереног метапоетичког расуђивања открива: „Песма је пре и после речи / када се речи не знају и када се забораве” (1961: 13). Наведеном поетичком самоспознајом лирски је посведочена раслојеност песниковог језичког осећања, којом су маркирани они аспекти говорног искуства чијим потискивањем са унутрашњег хоризонта субјект стиче моћ да у властиту егзистенцију призове аутентичну поетску реч. Међутим, ваља имати у виду да су оваквим песничким опредељењем истовремено евоцирана два Миљковићева поетичка постулата. Први је песник Ватре и ништа, говорећи о беспредметној природи поезије (која дематеријализује стварност, односно извесност замењује неодређеношћу, а постојеће могућним), дефинисао закључком: „У песми не сме ништа да се догађа, одиграва, развија, јер би то захтевало причање, нарацију, инвентарисање. Све што се догоди, мора да се догоди пре песме" (1972: 205 - Н. К.). Други постулат тиче се поетског феномена заборава, који је на Миљковићевој лествици поетичких вредности достигао статус песничко-стваралачког почела: „Почетак поезије је почетак заборава. [...] Метода заборава у поезији је у томе да се непосредни квалитет изрази далеком, наизглед неприступачном алузијом. [...] Где је почетак забо- 
рава? Тамо где стварност више није кадра да говори сама о себи језиком непосредности, тамо где се она преобратила у празнину јер се не може изрећи, јер саму себе у себи више не може дозвати по имену” (1972: 92).

Модернистичким осећањем недовољности речи, односно наслућивањем постојања смисла који вапи за уобличењем поетском речју, истовремено се опирући значењским стегама језика, захваћена је поетика Бећковићевих песничких почетака. О изразитој важности назначене метапоетичке антиномије говори разноликост њених конкретних лирских артикулација, и то унутар битно другачије како тематски и емоционално, тако и поетички заснованих песама. Иако Матија Бећковић лирски баштини замишљеност над питањем изрецивости, чиме у властити поетички лик утискује фундаментално становиште модерне поезије, у даљем песничком моделовању овог проблема неће следити ни симболистичку традицију херметизма достигнутог интензивним згушњавањем смисла нити надреалистичке тековине поетске неразумљивости остварене вербализовањем несвесних садржаја и уметничким поверењем у слободан след асоцијација некомпромитованих контролом разума. Уместо наведених модернистичких путања, песничко осећање недовољне изражајне потентности језика, нарочито присутно у Бећковићевим песмама о Вери Павладољској, срасло је са топосом класичне љубавне лирике према којем се женска лепота опева истицањем њене несместивости у тескобу ма колико значењски простране поетске речи: „Већ нема у српском језику речи на које се могу ослонити / Са којима бих поредио њене очи и онда мирно спавао" (2013: 56). Сумња у поетске могућности властитог речника, пак, у аутопоетички интонираној песми „Поново имам потребу да ћутим” дораста до размере самопорицања, те у исказима: „Мој сиромашни речник замењујем природом / И где год путујем / наила- 
зим на њу / И њена смела поређења [...] Она је дала облик птици / Смелије но што се усудио иједан песник / И ја се испод њених птица потписујем / Не додајући им готово ништа" (1965: 58), препознајемо чин одрицања лирског субјекта од скромних експресивних домета сопствених речи ради приклањања стваралачки надмоћној и нејезичкој, али не мање песничкој изражајности природе. Побуна против семантичке малокрвности поетских речи врхуни у полемички осмишљеној песми „Поезију више нико неће писати", у којој кукавичка немоћ поезије да изрази оно што жели да опева покреће устанак недопеваних предмета против значењског издајства њихових песничко-језичких ознака: „Опевани предмети напустиће песме / Незадовољни како су до сада тумачени и препевавани. / Све што је било предмет поезије / Устаће против ње и њеног кукавичлука!" (1965: 61). ${ }^{3}$

Осим што уписују и тон драматичности у неспокој песниковог поетичког самоуспостављања, стихови испуњени осећањем неизречја образују и својеврсни акустички простор у којем ће оштрином одсудности одјекнути готово радосни усклик изнађеног поетичког разрешења: „Упрљајмо се речима као деца трешњама” (1965: 11). Наведеним стихом из поетски саморасуђујуће песме „Доста је било” изречен је хеуристичким ентузијазмом обузет аутопоетички апел, којим се надилази безизлаз проблема неизрецивости оглашавањем новог односа према језику, у чијим се темељима жели обновити невиност првобитног доживљаја света и непомућено поверење према природи, мудра наивност непосредног додиривања речи и слобода потпуне преданости безаз-

3 Темељну анализу сложеног интертекстуалног односа између Миљковићевог поетског предсказања „Поезију ће сви писати” и Бећковићеве полемички интониране лирске реплике „Поезију више нико неће писати” видети у Стојановић 2003. 
леној спонтаности језичке игре. ${ }^{4}$ Није ли и Љубомир Симовић, истакавши да песма обитава не само после речи: кад се оне забораве него и пре: кад се речи не знају, сугестивно указао да је управо време пре познања језика, односно доба такорећи детиње језичке чистоте једно од природних станишта поезије?

Наредни стихови Бећковићеве песме потврђују да новонастало лирско осећање света проистиче из субјектовог коренито измењеног доживљаја природе речи, којима више не приличе ни статичност речничког окружења ни подвлашћеност механиком писаћих машина: „Разговарајмо о свему, а о свему једино и умем / говорити. / Употребимо све речи јер је сан сваке речи да буде употребљена / И избављена из речника и писаћих машина" (1965: 11). Будући да се подразумевана семантика избављења простире на оно што живи и поседује дух, начином на који је у наведеном стиху употребљен пасивни облик глагола избавити речи су сугестивно изведене из поља апстрактних феномена и приписано им је својство егзистентности. Следствено томе, поетски говор поприма обележја својеврсне метафизичке силе

4 Поставља се питање како херменеутички скрупулозно разумети смисао почетног и полемички екскламативног стиха на енергији поетичко-превратничког патоса засноване песме „Доста је било": „Доста је било римованих песама!” (1965: 11), унутар збирке већим делом сачињене управо римованим стиховима. Различити путеви тумачења могли би се дотицати: констатације о не тако ретком несагласју између метатекстуалних порука и иманентне поетике; претпоставке о постојању Бећковићеве поетичке аутоироније; или, пак, интерпретативне тврдње да се лирски глас обзнањен песмама слободног стиха суштински разликује од поетског субјекта израженог у метрички конвенционалнијим формама. Наведене недоумице убедљиво сведоче о сложености раних Бећковићевих песничких поступања, темељно обележених поетичким еклектицизмом и унутрашњим контрадикцијама. 
која, слободније речено, васкрсава речи из гробнице лексикографије. Да би се за далеким пореклом ове поетичке идеје могло поћи трагом разнородног симболистичког наслеђа, сведоче наводи Бранка Миљковића писани поводом поезије Рејмона Кеноа: „Речник је рудник одакле песник треба да црпе. Зар Маларме није писао своје песме помоћу Великог Ларуса. У речнику наша имена и речи и траве чекају своје поновно рођење” (1972: 179).

У наставку песме промењени доживљај речи протеже се и изван граница језика, а природа се третира као текст у настајању, односно запис подложан стваралачком дејству оловке, чијим потезима управља неутажива воља субјектовог самопрепознавања у свету: „Земљо засејана чудесима, излазим у природу са / црвеном оловком, / Прецртавам дрвеће, исправљам ваздух, стављам / примедбе, / Додајем и остављам недирнуто само оно што је налик мени" (1965: 11). Лирско Ја, у својству солипсистичког редактора природе, видљиво редукује на ексклузивне елементе привилеговане остварењем субјективног самопрепознавања, па унутар песничке визије остаје света онолико колико се субјективност светом распростире. Одлике испољеног лирског гледишта су потпуно опречне раније помињаној самопоричућој позицији поетског субјекта песме „Поново имам потребу да ћутим", који тоном самопрекорног признања обзнањује супремацију стваралачко-изражајних моћи природе.

Потоњи стихови „Доста је било”: „Мењају се односи међу речима и ја их данас познајем / као нико пре мене / Једини ја спуштам речи у епрувету и мућкам их" (1965: 13), осим што, сагледани у огледалу песничке традиције, дискретном асоцијативношћу у сећање призивају радикални авангардистичко-алхемичарски рецепт Тристана Царе за успостављање спрега међу речима и справљање песама („Направити дадаистичку песму”), истовремено нам указују да се у Бећковићевим песничким зачецима 
повремено чини одмак од реафирмисане романтичарске топике и ступа у поље ортодоксних идеја модерне поезије, преношењем поетичког акцента са срияа на реч, са страдана субјекта на истраживане језика, са мастила песничке крви на епрувете изражајних експеримената.

Поступним зрењем ново метапоетско поимање речи у песми „Дишем ваздух птичјим крилима замућен” доспева до конкретније аутопоетичке артикулације: „Шта је то што ја у песмама хоћу / Хоћу да речи у њима цвокоћу / Да врела комина у њима превире” (1965: 55). У метафоричном сугестијом исказаном поетском хтењу оцртана је тежња за досезањем свежине и силовитости једног интензивног и животношћу испуњеног песничког језика, чије се речи, очувавши језгровитост смисла и духовну пуноћу, свету обзнањују снагом пресне материјалности. Поетички идеал постаје језик који је тензија сабраног унутрашњег богатства учинила чулно осетним, те се субјект може са својеврсним телом песме упустити у разноликост егзистенцијалних односа побројаних стиховима: „Мазим те, песмо, грејем, премештам те / Постим, себе кудим, живим те, маштам те / Милујем ти речи као груди голубије / Чачкам ти душу док ме не убије!” (1965: 55). Тумачећи идеју младог Бећковића о речи перцептибилној попут објективног феномена, могло би се с довољно разлога и према принципу својеврсне херменеутичке аналогије, поновити управо оно што је Бранко Миљковић учинио интерпретирајући поетску чежњу Стевана Раичковића „за речима које не би биле мање стварне од онога што значе" (1972: 116): препознати поетички рецидив малармеовског поистовећивања бића и речи, односно изворно симболистичког онтичког схватања песничког језика, јер је „Маларме у поезији први реч и осет издигао до предмета. Речи нису ознаке ствари, већ ствари саме у својој актуелности” (Миљковић 1972: 226). 
И у Симовићевом раном песништву осећању семантички потрошених и поетски згаслих речи супротстављена је аутопоетичком жудњом прожета фантазија о речи већој од језика, која је исувише сирова и снажна да би била подвлашћена писмом и записана, која је одвећ животна да би остала апстрактна, и чијој природи више од звука и словног знака приличи материјална форма или телесни облик: „о како да ми дође реч снажна и сирова / ко дрво као извор ко ђубриште што кисне / реч коју не могу да обележе слова / што греје као светлост што као камен притисне / да је у устима осећам као залогај меса" (1958: 13). С једне стране, суштина тражене речи остаје недоступна лирском изрицању, али подлеже посредном назначавању одлика њене природе кроз поређења, док са друге, низање различитих и каткад међусобно контрадикторних компарација сведочи да ниједна од њих појединачно није довољна, а да њихово сабирање целину смисла чини парадоксалном.

Прве збирке Матије Бећковића, Метак луталииа и Тако је говорио Матија, одсудно су обележене наносима различитих песничких традиција и последичном поетичком разуђеношћу, чиме је пречен пут исцртавању јасних и постојаних линија његове песничке физиономије, али истовремено истрајним метапоетским гласом, који је на укупну лирску субјективност деловао уцелињујуће, не скривајући притом жудњу за темељним поетичким променама. Над Бећковићевом раном поезијом отуда искрсава сигнал претрајалости и знак скорог свршетка једне етапе модернистичког процеса, али се истовремено назире поетском самосвешћу наслућена неопходност досезања нове поетичке парадигме, коју ће установити потоња ровачка трилогија. 


\section{ЛИТЕРАТУРА}

Бећковић 2013: М. Бећковић, Метак луталиияа, репринт изд. из 1963, Београд: Booking.

Бећковић 1965: М. Бећковић, Тако је говорио Матија, Београд: Просвета.

Миљковић 1997: Б. Миљковић, Песме, Сремски Карловци: Каирос.

Симовић 1958: Љ. Симовић, Словенске елегије, Титово Ужице: Клуб студената.

Симовић 1961: Љ. Симовић, Весели гробови, Београд: Нолит.

Делић 2012: Ј. Делић, Уводна ријеч, у: Јован Делић, Драган Хамовић (ур.), О песмама, поемама и поетици Матије Бећковића, Београд: Институт за књижевност и уметност, Учитељски факултет, Требиње: Дучићеве вечери поезије, 9-14.

Душанић 2012: Д. Душанић, Шта је аутофикција?, Кюижевна историја, 44 (2012) 148, Београд: 797-810.

Јерков 1995: А. Јерков, Од птице до чоека, у: М. Вукићевић, Н. Вуковић, М. Ковачевић (прир.), Поетика Матије Бећковића, Никшић: Филозофски факултет, Подгорица: Октоих, 85-102.

Јовановић 1994: А. Јовановић, Поезија српског неосимболизма, историја једне песничке осећајности, Београд: „Филип Вишњић”.

Јовановић 2012: А. Јовановић, Љубав јака као смрт - о поеми „Кад дођеш у било који град” Матије Бећковића, у: Јован Делић, Драган Хамовић (ур.), О песмама, поемама и поетици Матије Бећковића, Београд: Институт за књижевност и уметност, Учитељски факултет, Требиње: Дучићеве вечери поезије, 283-310.

Кољевић 1978: Н. Кољевић, Иконобории и иконобранитељи, Београд: Нолит.

Лукић 1973: С. Лукић, Историја и поезија, у: Света Лукић (прир.), Савремена поезија, Београд: Нолит, 139-154. 
Микић 2003: Р. Микић, „У туђем смо срцу своје срце чули”, у: Радивоје Микић (прир.), Поезија Бранка Миљковића, нова mумачена, Ниш: Просвета, Гаџин Хан: Општинска библиотека, 271-291.

Милосављевић 1995: П. Милосављевић, Бећковић, постмодернизам, неоромантизам, у: М. Вукићевић, Н. Вуковић, М. Ковачевић (прир.), Поетика Матије Бећковића, Никшић: Филозофски факултет, Подгорица: Октоих, 161-180.

Миљковић 1972: Б. Миљковић, Сабрана дела, књига четврта, Критике, са делима и ауторима о песничкој уметности, прилози, Ниш: Издавачка установа „Градина”.

Негришорац 1999: И. Негришорац, Поетичка сложеница Бранислава Петровића, у: Радивоје Микић, Драган Хамовић (ур.), Бранислав Петровић, песник, Краљево: Народна библиотека „Радослав Веснић”, 41-72.

Новаковић 2003: J. Новаковић, Поезија као „патетика ума”: Бранко Миљковић и Пол Валери, у: Радивоје Микић (прир.), Поезија Бранка Миљковића, нова тумачень, Ниш: Просвета, Гаџин Хан: Општинска библиотека, 48-75.

Палавестра 2012: П. Палавестра, Послератна српска книжевност 1945-1970 и нена историја, Београд: Службени гласник.

Патић 1995: М. Пантић, Рани и зрели Бећковић, у: М. Вукићевић, Н. Вуковић, М. Ковачевић (прир.), Поетика Матије Бећковића, Никшић: Филозофски факултет, Подгорица: Октоих, 187-193.

Пантић 1999: М. Пантић, Божанствена комедија Бранислава Петровића, у: Радивоје Микић, Драган Хамовић (ур.), Бранислав Петровић, песник, Краљево: Народна библиотека „Радослав Веснић”, 99-106.

Париповић 2012: С. Париповић, Поигравање „малом мензуром” - Бећковићев сонетни облик, у: Јован Делић, Драган Хамовић (ур.), О песмама, поемама и поетиии Матије Бећковића, Београд: Институт за књижевност и уметност, Учитељски факултет, Требиње: Дучићеве вечери поезије, 379-402.

Поповић 2012: Р. Поповић, Поетички аспекти љубавног пјесништва Матије Бећковића, у: Јован Делић, Драган Хамовић 
(ур.), О песмама, поемама и поетици Матије Бећковића,

Београд: Институт за књижевност и уметност, Учитељски

факултет, Требиње: Дучићеве вечери поезије, 259-282.

Ракитић 1984: С. Ракитић, У трагању за Итаком, предговор у:

Велимир Лукић, Магла и лик, Београд: Просвета, 9-35.

Стојановић 2003: С. Стојановић, Песничка утопија и изванпеснички разлози, у: Радивоје Микић (прир.), Поезија Бранка Миљковића, нова тумачењь, Ниш: Просвета, Гаџин Хан:

Општинска библиотека, 254-270.

Џаџић 1965: П. Џаџић, Бранко Милковић или неукротива реч, Београд: Просвета.

Nemanja Karović

\section{METAPOETIC CONSCIOUSNESS IN THE EARLY POETRY OF MATIJA BEĆKOVIĆ}

This paper examines appearances of metapoetic consciousness in the collections of poems Metak lutalica and Tako je govorio Matija by Matija Bećković with an interpretative effort to be more precise in drawing out the complex poetic map of the poet's early work as well as to determine his attitude to the aesthetic ideas of Branko Miljković. The above collections rest on an open, late modernism sensitivity, free enough to cross numerous and diverse lines of the poetic tradition in the framework of the poetic equation, but also too self-conscious to attach the significance of an absolute poetic principle to any of them. However, one of the counterweight forces that keep the obvious diversity of Bećkovićs poetic feelings coherent and within the boundaries of the complex poetic subjectivity is the force of metapoetic consciousness. Its intensity and frequency make the collections Metak lutalica and Tako je govorio Matija works of deep poetic self-reflexivity. Special attention has been given to the analysis of poetic oscillations between reaffirmed romantic topoi and the revived symbolic poetic ideas. It is not 
about the final and irrevocable transition from one creative phase to another, but about a successive shift and occasional interweaving of often disparate poetic experiences, where individual poetic factors from one poem to another, from one cycle to another, become at times more sensitive and emphasized and at times more subtle and discreet. The paper emphasizes the dominant eclectic attitude of young Bećković towards diverse poetic tradition fields.

Key words: Matija Bećković, Branko Miljković, metapoetic consciousness, autopoetics, romantic topoi, symbolism, modernism. 